\title{
Gabriela Czapiewska
}

\section{Dialog międzypokoleniowy a aktywizacja społeczna osób starszych w środowisku wiejskim}

Streszczenie: Relacje międzypokoleniowe są podstawą funkcjonowania każdego społeczeństwa. Sposobem ich budowania jest dialog między pokoleniami, będący także drogą do przeciwdziałania i zapobiegania współczesnym problemom społecznym, wymaga on jednak aktywnego udziału zarówno osób starszych, jak i młodych. Artykuł stanowi próbę uchwycenia istoty dialogu międzypokoleniowego i podkreślenia jego roli w środowisku wiejskim; łączy teoretyczne rozważania z opisem praktycznych rozwiązań (przykład programu „Seniorzy w akcji”). Ważnym obszarem jest międzypokoleniowość, realizowana tak na poziomie zarządzania projektem (międzypokoleniowe pary animatorów), jak i na poziomie działań skierowanych do społeczności lokalnej (w której uczestniczą różne grupy wiekowe). Środowisko wiejskie umożliwia także budowanie więzi międzypokoleniowych dzięki relacjom sąsiedzkim, gdzie kontakty między wieloma pokoleniami są częścią codziennego życia, jak też w tzw. grupach interesów (np. w ramach organizacji pozarządowych czy świetlic wiejskich), których celem jest rozwiązywanie problemów lokalnych społeczności. Skuteczny dialog to wymiana wartości przynosząca zyski całej społeczności lokalnej.

Słowa kluczowe: dialog, pokolenie, relacje międzypokoleniowe, dialog międzypokoleniowy.

\section{Wprowadzenie}

Relacje, kontakty międzypokoleniowe to nieodłączny element funkcjonowania społeczeństw, w tym wiejskich społeczności lokalnych. Przemiany cywilizacyjne, postęp kulturowy, gospodarczy, ekonomiczny, technologiczny i zmiany w sferze obyczajowej przyniosły załamanie relacji międzypokoleniowych w rozumieniu tradycyjnym. Jeszcze kilkanaście lat temu relacje międzypokoleniowe, w tym zwłaszcza w społecznościach wiejskich, opierały się na szacunku oraz hierarchii

Dr Gabriela Czapiewska, Instytut Geografii Społeczno-Ekonomicznej i Turystyki, Akademia Pomorska, ul. Partyzantów 27, 76-200 Słupsk, gabriela.czapiewska@apsl.edu.pl, ORCID: 0000-0002-5638-9831. 
wynikającej z wieku (Raszeja-Ossowska 2016). W kulturach tradycyjnych, w których zasadniczą rolę odgrywał przekaz ustny i obyczaj, seniorzy byli traktowani jako skarbnica wiedzy wielu pokoleń. Doświadczenia następujących po sobie generacji były do siebie podobne i mocno osadzone w życiu wielopokoleniowej rodziny. Obecnie żyjemy w świecie, który szybko ewoluuje, a tempo tych zmian i postęp technologiczny sprawiają, że wiedza i informacje gromadzone przez całe życie równie szybko się dezaktualizują. Przemiany modelu rodziny i migracje zarobkowe powodują zanik rodzin wielopokoleniowych, co wpływa na ograniczanie kontaktu między seniorami a ludźmi młodymi. Więzi i zależności między pokoleniami rozluźniają się, w efekcie następuje utrwalanie się stereotypów i kształtowanie negatywnych postaw, i to tak wobec osób starszych, jak i wobec młodych (Tokarz-Kamińska 2013). Jednocześnie obie te grupy są najbardziej zagrożone dyskryminacją ze względu na wiek, jak również marginalizacją w swojej społeczności (Raszeja-Ossowska 2016).

Podstawą budowania solidaryzmu międzypokoleniowego będzie bez wątpienia umiejętność dialogu. Jest ona wielkim wyzwaniem, zwłaszcza w kontekście zmian demograficznych, wynikających ze starzenia się społeczeństw. Pociągają one za sobą konieczność dostosowania otoczenia społecznego do potrzeb seniorów. Polska jest jednym z najszybciej starzejących się krajów europejskich. Dane GUS wskazują, że na obszarach wiejskich do 2050 roku udział osób w wieku 65+ przekroczy 30\% (Sytuacja... 2014).

Dialog międzypokoleniowy to jednocześnie istniejące obiektywnie, spontaniczne zjawisko społeczne oraz przedmiot badań i proces stymulowany przez centra akademickie i aktywistów społecznych w celu pogłębienia wzajemnego zrozumienia generacji oraz poprawy stosunków międzypokoleniowych (Hoff 2013). Dialog między generacjami jest sposobem przeciwdziałania i zapobiegania współczesnym problemom społecznym, wymaga jednak na równi aktywnego udziału zarówno osób starszych, jak i młodych.

Relacje międzypokoleniowe dostarczają swoistego kontekstu, w ramach którego człowiek dorasta i osiąga dojrzałość. Tworzą tło, na którym ludzie odmierzają, odznaczają i wartościują swoje starzenie się. Jakość relacji międzypokoleniowych kształtuje zaś uczucia, myśli i działania wobec innych (Biggs, Lowenstein 2011). Współczesne pokolenia, choć żyjące w tym samym czasie i miejscu, żyją w istocie w dwóch różnych „światach”. Stanowią nie tylko odmienne środowiska czy warstwy społeczne, ale i odmienne kultury (Godlewski 2002). Każde pokolenie tworzy więc własną narrację rzeczywistości. Ważne jest, aby była ona dostępna dla innych pokoleń i tym samym formowała przestrzeń dla prawdziwego szacunku i zrozumienia. Dialog między pokoleniami jest ważnym wyzwaniem naszych czasów. 
Artykuł stanowi próbę ujęcia istoty dialogu międzypokoleniowego i podkreślenia jego wagi w środowisku wiejskim. W tym celu opracowanie łączy teoretyczne rozważania z opisem praktycznych rozwiązań (przykład konkursu „Seniorzy w akcji”). Podjęta problematyka jest szeroka i trudna do całościowego zgłębienia, toteż z konieczności skupiono się tylko na wybranych jej aspektach - tych, które stanowią pewien drogowskaz do dalszych rozważań i poszukiwań badawczych. Artykuł jest próbą odpowiedzi na pytania: jak kształtują się relacje międzypokoleniowe na wsi polskiej? Jaką rolę odgrywa dialog międzypokoleniowy w środowisku wiejskim? Zastosowane w pracy metody badawcze to przede wszystkim krytyczna analiza porównawczo-opisowa literatury przedmiotu oraz wywiad swobodny z uczestnikami projektów realizowanych w ramach konkursu „Seniorzy w akcji”, wspierającego dialog międzypokoleniowy.

\section{Definiowanie pokolenia i dialogu w relacjach międzypokoleniowych}

Definicje pokolenia odwołują się na ogół do najbardziej utrwalonej w socjologii propozycji autorstwa Karla Mannheima (1966), przyjmującej, że osoby urodzone w danej kohorcie wieku doświadczają tych samych zdarzeń socjopolitycznych, w kręgu których wzrastają, i to wyróżnia ich jako specyficzną grupę (Spiker 2008). Autor wskazuje dwa typy społeczeństw: dynamiczne i statyczne. Społeczeństwa dynamiczne dążą do współpracy z młodzieżą, gdyż są zainteresowane szybkimi zmianami i rozwojem. Przeciwieństwem są społeczeństwa statyczne (tradycyjne), w których zmiany zachodzą powoli i opierają się na doświadczeniach starej generacji (Griese 1996).

Pojęcie pokolenia (generacji) nie jest wykorzystywane w literaturze przedmiotu w sposób jednoznaczny (Klimczuk 2010). Na wielość interpretacji pojęcia wskazuje klasyczna typologia autorstwa Marii Ossowskiej (1963; zob. tabela 1).

Zgodnie ze słownikiem języka polskiego „pokolenie” lub „generacja” (od łac. generatio - rodzenie, tworzenie) to termin mający kilka konotacji. W naukach biologicznych wiąże się z urodzeniem, ale większość definicji (kulturowych i antropologicznych) traktuje pokolenie jako grupę osób w podobnym wieku, ukształtowaną przez określone obyczaje, tradycję, kulturę i historię. Poszczególne osoby mogą rozpoznać w swoich losach wydarzenia, postaci, postawy i aktywności, które je jednoczą. W ten sposób zdefiniowane pokolenie ma swoje unikatowe cechy, wiedzę i umiejętności. Unikatowość ta jest podstawą i istotą interakcji (wzajemnych kontaktów) między różnymi pokoleniami. Z kolei w ujęciu kulturowym pokolenie to zbiorowość społeczna składająca się z osób, które w tym samym czasie zaczynały dorosłe życie i kształtowały swoją osobowość, a wydarzenia historyczne wpływające 
na trajektorie ich indywidualnych losów i na sferę ich przeżyć formowały ich postawy (Niezabitowski 2010).

Tabela 1. Główne znaczenia, cechy i wymiary pojęcia „pokolenie”

Table 1. Main meanings, features and dimensions of the concept of a generation

\begin{tabular}{lll}
\hline \multicolumn{1}{c}{ Znaczenie } & \multicolumn{1}{c}{ Główne cechy } & Zakres analizy \\
\hline $\begin{array}{l}\text { Ogniwo w ciągu } \\
\text { Genealogicznym }\end{array}$ & $\begin{array}{l}\text { Biologiczna zależność pomiędzy rodzicami } \\
\text { a dziećmi; miejsce w schemacie } \\
\text { pokrewieństwa }\end{array}$ & Rodzina \\
Ogniwo w ciągu kulturowym & $\begin{array}{l}\text { Podział ról społecznych analogiczny do } \\
\text { relacji rodzice-dzieci, np. nauczyciel-uczeń }\end{array}$ & Krąg kulturowy \\
$\begin{array}{l}\text { Zbiór osób w zbliżonym } \\
\text { wieku, w przedziale } \\
\text { trzydziestu lat }\end{array}$ & $\begin{array}{l}\text { Założenie, że ojciec jest przeciętnie o 33 lata } \\
\text { starszy od dzieci }\end{array}$ & Społeczeństwo \\
$\begin{array}{l}\text { Zbiór osób w poszczególnych } \\
\text { fazach życia }\end{array}$ & $\begin{array}{l}\text { Ujęcie ahistoryczne; porównywanie } \\
\text { analogicznych grup wieku w różnych } \\
\text { epokach i społeczeństwach; przechodzenie } \\
\text { tych samych osób przez różne fazy ich życia }\end{array}$ & \\
$\begin{array}{l}\text { Wspólnota postaw i hierarchii } \\
\text { wartości }\end{array}$ & $\begin{array}{l}\text { Ujęcie historyczne; wspólne przeżycia } \\
\text { i doświadczenia, np. wojna, przełom ustrojowy }\end{array}$ & Społeczeństwo \\
\hline
\end{tabular}

Źródło: opracowanie własne na podstawie Ossowska (1963, s. 50).

Source: own study based on Ossowska (1963, p. 50).

Judith E. Phillips i in. (2010) wyróżniają cztery podejścia do definiowania terminu "pokolenie":

1) antropologiczne - w zakresie więzi i ról rodzinnych jednostek oraz pokrewieństwa i posiadania wspólnego przodka (np. ojciec, babka, pradziadek);

2) socjologiczne - dotyczące podobieństwa kulturowego w ramach traumatycznego doświadczenia oddziałującego na świadomość grupy osób wkraczających w dorosłość; określa ono przebieg życia i definiowania rzeczywistości w sposób odmienny niż w poprzednich pokoleniach (np. pokolenie Kolumbów, pierwszej „Solidarności”);

3) demograficzne i ekonomiczne - prezentujące grupy osób w zbliżonym wieku, urodzonych w podobnym okresie;

4) polityki społecznej - odnoszące się do aktywności zawodowej i uprawnień socjalnych, przypisanych jednostkom w danych grupach wieku (np. wiek obowiązkowego pobierania nauki) oraz grup docelowych polityk wyodrębnionych przez podobieństwo faz cyklu życia (np. młodość, dorosłość, starość). 
Dialog na przestrzeni wieków był różnie pojmowany i przechodził różne fazy, aż do wyodrębnienia się filozofii dialogu (dialogiki); jej twórcą jest Martin Buber. Dialog stanowi formę komunikacji - rozmowy oferującej kompromis dla obu stron: młodego człowieka oraz osoby starszej; jest także podstawą solidarności międzypokoleniowej. Budowanie tej ostatniej na drodze dialogu zaspokaja ważną wśród osób starszych potrzebę bycia użytecznym (Osoby starsze... 2012).

Próby uporządkowania pojęć dotyczących kwestii relacji międzypokoleniowych podjął się Piotr Szukalski (2002). Rozróżnia on znaczenia takich terminów, jak relacja, więź, solidarność i kontrakt międzypokoleniowy (tabela 2). Relacje i kontrakt nie podlegają wartościowaniu, podczas gdy więź i solidarność przeciwnie - nacechowane są pozytywnie. Istnienie sprzeczności prowadzi do ambiwalencji międzypokoleniowej - współistnienia odmiennych postaw i sposobów myślenia o relacjach pokoleniowych na poziomie mikro (poszczególnych rodzin) i makro (całych społeczeństw) (Bengtson i in. 2002; Klimczuk 2010; Szukalski 2012). Stosunki między ludźmi starymi a młodymi na poziomie makro (społeczeństw i grup) mogą być objaśniane odpowiedziami na pytania: kto i co otrzymuje oraz jakim/czyim kosztem, zaś na poziomie mikro (rodzin i jednostek): kto jest socjometryczną gwiazdą w wymianie międzypokoleniowej i czy zawsze jest to pokolenie środkowe, a także które z pokoleń daje najwięcej i stosunkowo mniej otrzymuje/ żąda? (Koyano 2003; Woźniak 2012).

Tabela 2. Typy relacji międzypokoleniowych

Table 2. Types of intergenerational relationship

\begin{tabular}{lll}
\hline \multicolumn{1}{c}{ Pojęcie } & \multicolumn{1}{c}{ Główne cechy } & \multicolumn{1}{c}{ Zakres zobowiązań } \\
\hline Solidarność & $\begin{array}{l}\text { Wzajemna odpowiedzialność wobec innych pokoleń; } \\
\text { uwzględnianie w podejmowanych działaniach interesów, } \\
\text { potrzeb i opinii innych generacji }\end{array}$ & $\begin{array}{l}\text { Postawa „musimy coś } \\
\text { zrobić” }\end{array}$ \\
Relacja & $\begin{array}{l}\text { Ogół stosunków między jednostkami lub grupami z różnych } \\
\text { pokoleń; interakcje, opinie, postawy, stereotypy }\end{array}$ & Brak zobowiązań \\
Więź & $\begin{array}{l}\text { Poczucie łączności biologicznej, kulturowej, ekonomicznej } \\
\text { z innymi pokoleniami; pozytywne nastawienie wobec } \\
\text { jednostek należących do innych pokoleń }\end{array}$ & $\begin{array}{l}\text { Postawa „powinniśmy } \\
\text { coś zrobić” }\end{array}$ \\
Kontrakt/ & $\begin{array}{l}\text { Spisane lub nie reguły redystrybucji wyznaczników } \\
\text { statusu społecznego (bogactwo, władza, prestiż) między } \\
\text { pokoleniami }\end{array}$ & $\begin{array}{l}\text { Postawa „zróbmy to } \\
\text { i to" }\end{array}$ \\
\hline
\end{tabular}

Źródło: opracowanie własne na podstawie Szukalski (2010, s. 87-88; 2012, s. 47-49).

Source: own study based on Szukalski (2010, pp. 87-88; 2012, pp. 47-49). 
Spojrzenie na relacje międzypokoleniowe przez pryzmat historii ukazuje dwa przeciwstawne bieguny, pomiędzy którymi rozpościera się wielość możliwych rodzajów wzajemnego kontaktu między grupami - od gerontofobii do gerontokracji. Pierwsza z nich - gerontofobia - oznacza lęk przed starością i starszymi ludźmi. Prowadzi ona do traktowania ludzi starych jako ciężaru społecznego, stanowiąc źródło uprzedzeń i dyskryminacji. Drugi biegun - gerontokracja - wskazuje na przywileje i społeczny prestiż starców, ceni się tu ich wiedzę i doświadczenie życiowe. Starzy ludzie darzeni są szacunkiem i uznaniem, stanowią dla młodszych pokoleń autorytet i wsparcie (Magiera 2010; Kalinowska 2011). Dość trudne jest zrozumienie relacji międzypokoleniowych bez szerszego uwzględnienia współczesnych przemian społeczno-kulturowych. Ważne jest, by pamiętać, że dialog między najmłodszymi i najstarszymi generacjami mogą ułatwiać różne obszary życia społecznego, m.in.: kultura, sztuka, sport czy edukacja (w tym poradnictwo, warsztaty, szkolenia, ustawiczne kształcenie, wolontariat).

Międzypokoleniowy przekaz wartości jest podstawą rozwoju społecznego, w tym również rozwoju kultury. Dokonuje się dzięki wielu działaniom podejmowanym przez kolejne pokolenia żyjące $\mathrm{w}$ danym społeczeństwie. $\mathrm{W}$ dialogu międzypokoleniowym nie chodzi o ujednolicenie poglądów, lecz o ich różnorodność. Zdaniem Barbary Szatur-Jaworskiej i in. (2006) w stosunkach między pokoleniami potrzebne są kultura, takt i sztuka dyplomacji, a na pierwszym miejscu - zdrowy rozsądek i sprawiedliwość, bo tam, gdzie są one naruszone, nieuchronnie dochodzi do pretensji i konfliktów.

Margaret Mead (1978) już kilkadziesiąt lat temu zwracała uwagę na pogłębianie się dystansu międzypokoleniowego. Sformułowała wówczas koncepcję trzech kultur: postfiguratywnej, kofiguratywnej i prefiguratywnej. W każdej z nich sytuacja człowieka starego jest inna, a tym samym wzajemne relacje między przedstawicielami różnych pokoleń układają się w odmienny sposób. Kultury postfiguratywne opierają się na autorytecie z przeszłości. Cały dorobek kultury danej społeczności przekazywany jest dzieciom i młodzieży przez starsze pokolenie (Kalinowska 2011). Zatem w kulturze postfiguratywnej starsze pokolenie jako bardziej doświadczone jest pokoleniem wychowującym (społeczeństwo tradycyjne). Z kolei w kulturze kofiguratywnej pokolenia zmagają się z coraz to poważniejszymi wyzwaniami ludziom starym z trudnością udaje się dostosować do zmian (społeczeństwo modernistyczne). Młodsze pokolenia uczą się życia, przejmując wzorce zachowań swoich rówieśników. Starsi nadal należą do tej grupy, która dzieli się autorytetem z młodszymi, jednak ich oddziaływania na młodą jednostkę są ograniczone. Kultury kofiguratywne doprowadziły do rozbicia wielopokoleniowych rodzin i do ich zatomizowania. W takich rodzinach dostrzega Mead przyczynę wzrastania dystansu 
międzypokoleniowego, gdyż brakuje w nich podtrzymywania więzi międzypokoleniowej.

Na szczególną uwagę zasługuje jednak wizja kultury prefiguratywnej. Autorka przewidziała, że zwiększający się wraz z postępem technologicznym i cywilizacyjnym dystans międzypokoleniowy spowoduje, iż starszym osobom coraz trudniej będzie dostosowywać się do rzeczywistości tworzonej przez młodzież. Pokolenia żyją w różnych „światach” nieznanych sobie nawzajem (społeczeństwo postmodernistyczne).

\section{Przestrzeń dialogu międzypokoleniowego w społecznościach wiejskich}

Kwestie relacji międzypokoleniowych stanowiły ważny wątek w długiej tradycji badań nad kulturą wsi polskiej. Przemiany społeczności wiejskiej - do momentu, gdy nasiliły się migracje z miast - były przede wszystkim procesem przekształcania się i różnicowania warstwy chłopskiej (Zawistowicz-Adamska 1958). Istotę kultury chłopskiej stanowiły elementarne więzi międzyludzkie, czyli model rodziny wraz z jego wprzęgnięciem w całość życia (Markowska 1976). Kultura chłopska była kulturą wspólnotowości i budowania trwałych relacji przekraczających nie tylko rodzinę nuklearną, lecz także wielopokoleniową (Mencwel 2017). Rodzina jawiła się nie tylko jako podstawowa, wielofunkcyjna komórka życia społecznego, ale to także wokół niej koncentrowały się rytuały konstytuujące doroczny cykl życia (Michalska 2019). Często starsze pokolenie - będące jedynym źródłem informacji - przekazywało młodym życiową wiedzę i mądrość ludową jako kulturowe dziedzictwo przodków. Zasadniczą treść przekazu międzypokoleniowego stanowił system wartości, w tym wzorce osobowe.

Zasadniczą rolę w formowaniu tożsamości wiejskiej odgrywała praca na roli, będąca wyznacznikiem postaw ludzkich we wszystkich dziedzinach życia (Chałasiński 1964, 1984; Szczepański 1988). Ziemia stanowiła podstawę utrzymania, ale także łącznik z dziedzictwem przodków, tworząc specyficzną relację chłopa z ziemią (Komendera 1985; Halamska 1991). Stosunek do ziemi i pracy na roli był niezwykle istotnym kryterium wartości mieszkańca wsi (Bukraba-Rylska 2008). Człowiek leniwy, niedbale gospodarujący zasługiwał na pogardę, mało sprawny - na lekceważenie i politowanie, pracowity, ofiarny i zdolny - na szacunek (Drozd-Piasecka 1991). Ziemię traktowano jako ojcowiznę, czyli dziedzictwo przeszłych pokoleń, które należy przekazać własnym dzieciom. W ten sposób kultura chłopska była kulturą międzypokoleniową, budującą trwałe więzi między światem zmarłych przodków a jeszcze nienarodzonych potomków (Mencwel 2017).

Kolektywizacja polskiego rolnictwa w połowie XX wieku doprowadziła do zakłócenia podstawowych funkcji rodziny wiejskiej: zerwała rodzinne, emocjonalne 
i ekonomiczne więzi członków chłopskich rodzin z gospodarstwem. Ziemia przestała już być postrzegana jako wartość trwała, nieustępliwa i pozamaterialna, a gospodarstwo nie stanowiło pasji życiowej, lecz źródło dochodów potrzebnych do egzystencji rodziny. Zdaniem Piotra Nowaka (2012) w zamian pojawiły się dwa nowe elementy tożsamościowe budujące etos nowej, kształtującej się od lat dziewięćdziesiątych kultury wiejskiej. $Z$ dawnego przywiązania do ziemi i pracy pozostało przywiązanie do żywności, zwłaszcza jej jakości. Rodzinę, gdzie trzy pokolenia wspólnie uprawiały pole (wielopokoleniową), zastąpiła charakterystyczna dla współczesnej kultury miejskiej rodzina nuklearna. Istotnym elementem tożsamości „nowej wsi polskiej” było także traktowanie jej w kategoriach „małej ojczyzny”.

Barbara Fedyszak-Radziejowska (2002) zauważa, że dla ludności wiejskiej jeszcze na początku XXI wieku praca na roli była ważnym kryterium w wyborze lokalnych liderów, a największym zaufaniem cieszyły się osoby łączące aktywność o charakterze rolniczym z działalnością społeczno-kulturalną.

Oprócz rolnictwa także religia wywierała ogromny wpływ na całokształt życia społecznego w kulturze polskiej wsi. Jej oddziaływanie przejawiało się we wszystkich niemal sferach życia: obrzędach, obyczajowości, a także w organizowaniu przestrzeni domostwa (Sulima 2008). Odgrywała ona kluczową rolę w porządkowaniu przestrzeni i czasu życia chłopa, czego dowodem centralna rola miejsc kultu czy przestrzeni sakralnych, takich jak cmentarze na wsiach.

We wspólnocie wiejskiej więzi rodzinne przenikały się z sąsiedzkimi, a wokół nich kształtowała się wspólnota wioskowa, w której chłop czuł się pełnoprawnym i aktywnym członkiem (Czerwiński 1969; Wieruszewska 1991). Rodzina, sąsiedztwo, społeczność wioskowa i Kościół tworzyły dość zwarty system społeczno-wychowawczy, w ramach którego przekazywano jednostce normy i wzory zachowań, kształtowano zainteresowania, aspiracje, styl życia i świadomość społeczno-moralną młodego pokolenia.

Obecnie wyzwaniem jest rozwijanie przestrzeni do kontaktów międzypokoleniowych także poza rodziną, np. w szkole czy pracy (Tokarz-Kamińska 2013). Lokalne społeczności wiejskie mogą budować więzi międzypokoleniowe zarówno dzięki relacjom sąsiedzkim, gdzie kontakty między wieloma pokoleniami są częścią codziennego życia, jak i w tzw. grupach interesów (np. w organizacjach pozarządowych czy świetlicach wiejskich). Współcześnie nowe więzi i stosunki społeczne przekraczają z reguły wąskie ramy dawnego sąsiedztwa. Zwłaszcza mobilność geograficzna i społeczna niosą ze sobą niestałość wielu instytucji społecznych i kontaktów międzyludzkich, utrudniając głębsze więzi wspólnotowe.

Wiejskie społeczności lokalne powinny także sprzyjać komunikacji między młodymi i starszymi pokoleniami, szczególnie jeśli chodzi o tworzenie warunków i wspieranie inicjatyw organizacji pozarządowych, szkól, instytucji kultury itp., 
w ramach inicjatyw sąsiedzkich, w świetlicach wiejskich, w grupach i ruchach obywatelskich (np. stowarzyszeniach, fundacjach, kołach gospodyń wiejskich). Te nowe kontakty międzypokoleniowe wymagają oparcia nie na hierarchii, lecz na partnerstwie. Jest to nowa sytuacja, która wymaga otwartości na zamianę ról i wzajemne uczenie się, a przede wszystkim wzajemne słuchanie (Raszeja-Ossowska 2016). Istotne jest dostrzeganie potrzeb i potencjału każdego $\mathrm{z}$ angażowanych pokoleń. Skuteczny dialog to wymiana wartości, która jest cenna dla całej społeczności lokalnej.

O korzyściach płynących z dialogu międzypokoleniowego można i należy mówić z perspektywy zarówno pokolenia osób starszych, jak i pokolenia ludzi młodych. Seniorzy odczuwają wzrost poczucia bycia zauważonym i potrzebnym, a relacje międzygeneracyjne dają szansę na wyjście z alienacji wynikającej z dystansu kulturowego. Z kolei ludzie młodzi nawiązują bliższe relacje z osobami w późnej dorosłości, uzyskując tym samym szansę rozwoju kompetencji kulturowych (otwartości, tolerancji, szacunku). Tą drogą budują uznanie dla intelektualnej i społecznej aktywności osób starszych (Osoby starsze... 2012).

Dialog międzypokoleniowy charakteryzuje: akceptacja i zrozumienie siebie nawzajem oraz swojej obecności w przestrzeni publicznej, wzajemność i aktywność obustronna, komunikacja, czyli poznanie swoich potrzeb i oczekiwań, a także solidarność zakładająca korzyści dla wszystkich. Osoby młode oczekują dialogu, a nie mentoringu, na który nastawione są z kolei osoby starsze. Seniorzy natomiast chcą uczyć patriotyzmu, dobrego życia i tego, co wypada - chcą wychowywać (Wiśniewska 2017). Jednakże w dialogu międzypokoleniowym nie chodzi przecież o ujednolicenie poglądów, lecz o ich różnorodność. Istotne jest wykorzystanie potencjału seniorów, i to tak $\mathrm{w}$ wymiarze prywatnym (w życiu rodzinnym), jak i w wymiarze publicznym ( $w$ życiu społecznym). Na ten potencjał składają się (Wnuk 2013):

- mądrość życiowa (wiedza życia), wynikająca ze zdobytej wiedzy, nabytych kompetencji oraz bogactwa duchowego (odpowiedzialność, opiekuńczość, rozwaga, równowaga, empatia);

- potencjał warunkujący życie rodzinne;

- potencjał społeczny (relacyjny), wyrażający się zaangażowaniem w życie społeczne;

- potencjał psychologiczny - optymizm, wiara we własne możliwości, posiadanie siły woli i uporczywość w osiąganiu celów, umiejętność trwania w trudnych sytuacjach problemowych;

- potencjał przekazu kulturowego dotyczący pamięci historycznej i patriotycznej: miasta, regionu, kraju; 
- potencjał dotyczący wiedzy zawodowej, w tym w sposób szczególny profesji wymierających.

Ważne dla dialogu starszych i młodych są (Wiśniewska 2017):

- nieocenianie, akceptacja różnorodności postaw, doświadczeń;

- ciekawość drugiego człowieka oraz otwartość na wzajemne słuchanie i uczenie się;

- dbałość o integrację, szukanie wspólnych przestrzeni (pasje, doświadczenia);

- tworzenie atmosfery bycia razem, a nie wychowywania, pouczania;

- budowanie poczucia zaangażowania wobec siebie nawzajem;

- przełamywanie stereotypów wiekowych;

- pełne uczestnictwo każdego pokolenia - zaangażowanie uczestników w dialogu i poczucie wpływu na jego przebieg i rezultaty.

Zidentyfikowanie działań międzypokoleniowych silnie się wiąże z potrzebą budowania spójnych i zintegrowanych społeczności lokalnych, odpowiadających na potrzeby różnych grup i jak najpełniej korzystających z ich zasobów. Rozwijanie przedsięwzięć międzypokoleniowych stanowi odpowiedź na wiele wyzwań, z którymi mierzą się lokalne społeczności. W Polsce perspektywa międzypokoleniowa jest także coraz częściej włączana do planowania programów, aktywizujących osoby starsze i programów integracji społeczności lokalnych - na poziomie ogólnopolskim, regionalnym czy lokalnym (Tokarz-Kamińska, Krzyżanowska 2012). Doświadczenia krajów, które od lat inwestują w programy oparte na współpracy osób starszych z młodymi, wskazują, że współpraca pokoleń może być wykorzystywana jako skuteczne narzędzie zaspokajania potrzeb różnych grup i rozwiązywania problemów w środowisku wiejskim.

W społecznościach lokalnych międzypokoleniowo można działać w takich obszarach, jak: dziedzictwo kulturowe (np. wspomnienia, lokalna historia, tradycje i obrzędy); sprawy obywatelskie (np. działania na rzecz rozwoju sołectwa, edukacji); pasje i zainteresowania (np. kolekcjonerstwo); projekty artystyczne (np. teatralne, muzyczne, plastyczne); międzypokoleniowa wymiana umiejętności (np. warsztaty, seminaria, konferencje); wolontariat młodych osób na rzecz osób starszych i odwrotnie (np. w zakresie opieki, w zakresie edukacji); działania wokół nowych technologii (np. młodzi przewodnikami starszych po świecie technologii cyfrowych); inicjatywy rodzinne, wzmacniające więzi wielopokoleniowe (tabela 3). 
Tabela 3. Typy projektów międzypokoleniowych realizowanych w środowisku wiejskim

Table 3. Types of intergenerational projects implemented in a rural environment

\begin{tabular}{|c|c|}
\hline Rodzaj projektu & Wyszczególnienie \\
\hline Projekty artystyczne & $\begin{array}{l}\text { - Projekty teatralne (teatr międzypokoleniowy, teatr tańca) } \\
\text { - Projekty fotograficzne, filmowe, taneczno-muzyczne (chór, taniec, } \\
\text { warsztaty jazzowe) } \\
\text { - Projekty, korzystające z różnych metod rękodzieła (dzierganie, } \\
\text { warsztaty biżuterii, szycia czy filcowania) }\end{array}$ \\
\hline $\begin{array}{l}\text { Projekty regionalno- } \\
\text { historyczne }\end{array}$ & $\begin{array}{l}\text { - Zbieranie informacji o historii miejscowości i jej mieszkańcach, } \\
\text { o tradycjach i zwyczajach regionalnych (spisywanie wspomnień, } \\
\text { starych zabaw czy pieśni, opracowywanie przewodników) } \\
\text { - Projekty promujące lokalne zwyczaje }\end{array}$ \\
\hline Projekty edukacyjne & $\begin{array}{l}\text { - E-learning } \\
\text { - Zajęcia wspierające seniorów w korzystaniu z nowych technologii } \\
\text { - Wspólne czytanie }\end{array}$ \\
\hline Projekty rewitalizacyjne & $\begin{array}{l}\text { - Projekty nastawione na działania w przestrzeni publicznej: } \\
\text { sadzenie kwiatów, wytyczanie trasy rowerowej, rewitalizacja klatki } \\
\text { schodowej, zagospodarowanie placu zabaw, działania sąsiedzkie }\end{array}$ \\
\hline $\begin{array}{l}\text { Projekty integracyjno- } \\
\text { artystyczne }\end{array}$ & $\begin{array}{l}\text { - Spotkania kobiet z dwóch pokoleń wokół wspólnych pasji } \\
\text { - Gry i zabawy wielopokoleniowe } \\
\text { - Czytanie i wystawianie bajek } \\
\text { - Wspólne spędzanie czasu, powiązane z jakąś aktywnością, } \\
\text { np. malowanie, dzierganie, wyklejanie itp. }\end{array}$ \\
\hline $\begin{array}{l}\text { Projekty promujące } \\
\text { wolontariat }\end{array}$ & $\begin{array}{l}\text { - Promocja wolontariatu osób starszych (np. wolontariat } \\
\text { w placówce wsparcia dziennego) } \\
\text { - Szkolenia wolontariuszy - seniorów }\end{array}$ \\
\hline Projekty obywatelskie & - Debaty, seminaria, fora na tematy istotne dla społeczności \\
\hline $\begin{array}{l}\text { Projekty promujące } \\
\text { przedsiębiorczość }\end{array}$ & $\begin{array}{l}\text { - Tworzenie systemu wspierającego lokalnych twórców rękodzieła } \\
\text { - Angażowanie osób starszych w tworzenie marki lokalnej }\end{array}$ \\
\hline
\end{tabular}

Źródło: opracowanie własne na podstawie Raszeja-Ossowska (2016, s. 10).

Source: own study based on Raszeja-Ossowska (2016, p. 10).

Programy międzypokoleniowe służą m.in. celowej, zaplanowanej w czasie wymianie zasobów między młodszymi i starszymi generacjami. Wymiana ta przynosi wiele korzyści tak indywidualnych, jak i społecznych:

- pozwala wyjść poza stereotypy i wyznaczać nowe role społeczne;

- pomaga w zaspokajaniu potrzeb dotyczących zaangażowanych generacji;

- angażuje przynajmniej dwa pokolenia niepołączone więziami rodzinnymi;

- prowadzi do wzajemnego zrozumienia między młodymi i starszymi generacjami, podnosi też samoocenę obu grup; 
- pomaga w rozwiązywaniu lokalnych problemów,

- rozwija relacje i więzi międzypokoleniowe.

Realizacja działań międzypokoleniowych w lokalnych społecznościach wiejskich może przyczynić się do wzmocnienia rozwoju takich obszarów, jak (RaszejaOssowska 2016):

- budowanie aktywnej społeczności lokalnej;

- wzmacnianie wspólnoty lokalnej;

- promocja działań na rzecz społeczeństwa obywatelskiego;

- obniżenie poczucia zagrożenia przestępczością dzięki lepszemu porozumieniu pokoleń;

- przeciwdziałanie wykluczeniu, izolacji społecznej i dyskryminacji ze względu na wiek;

- wzmocnienie więzi sąsiedzkich.

\section{Działania międzypokoleniowe w społecznościach wiejskich na przykładzie programu „Seniorzy w akcji”}

Społeczna potrzeba integracji międzypokoleniowej, opartej na życzliwej współpracy, to podstawowa zasada we współczesnym świecie. Obecnie istnieje wiele przedsięwzięć, które wspomagają uczestnictwo osób starszych w życiu społecznym, dają im szansę dalszego uczenia się oraz umożliwiają dzielenie się wiedzą i doświadczeniem. Przykładem takiej inicjatywy jest realizowany od 2008 roku ogólnopolski konkurs dotacyjny pn. „Seniorzy w akcji” inkubator + dotacje. Stanowi on odpowiedź na wyzwania wynikające z niskiej aktywności społecznej osób starszych na obszarach wiejskich, rosnącego dystansu międzypokoleniowego i negatywnych stereotypów dotyczących starości. Zasadniczym celem konkursu ${ }^{1}$ jest wsparcie

1 Prowadzi je Towarzystwo Inicjatyw Twórczych „ę". Funkcjonuje ono od 2002 roku i realizuje projekty społeczno-kulturalne na obszarze Polski. Zgodnie ze statutem celem stowarzyszenia jest: animacja kultury w społecznościach lokalnych, zwiększanie dostępności do kultury i edukacji, wspieranie i integracja młodych twórców: profesjonalistów i amatorów, wyrównywanie szans edukacyjnych dzieci i młodzieży, zwiększenie udziału osób starszych w życiu społecznym oraz tworzenie i wspieranie form współpracy międzypokoleniowej, wspieranie międzynarodowej współpracy kulturalnej i edukacyjnej, promocja integracji europejskiej, rozwój tolerancji i dialogu międzykulturowego, promocja kultury polskiej w kraju i za granicą, testowanie i tworzenie nowych modeli działania w obszarze kultury, wzmacnianie i tworzenie mechanizmów partycypacji obywatelskiej. Stowarzyszenie realizuje cele przez: organizację warsztatów, szkoleń, kursów, konferencji, targów, wystaw, pokazów filmowych, wydarzeń artystycznych, imprez, staży, rezydencji twórczych, wolontariatu oraz konkursów w kraju i za granicą; prowadzenie badań w obszarze kultury i życia społecznego; organizację projektów międzynarodowych; innowacyjne programy społeczno-kulturalne; działalność wydawniczą; produkcję i upowszechnianie utworów filmowych, fotograficznych i innych utworów audiowizualnych; współpracę z instytucjami państwowymi, samorządowymi i pozarządowymi, sektorem gospodarczym oraz środkami masowego przekazu w kraju 
przedsięwzięć, które angażują osoby starsze do działania na rzecz otoczenia, uruchamiają inicjatywy oparte na współpracy międzypokoleniowej, a także sprzyjają rozwojowi wolontariatu osób starszych i wzmocnieniu rzecznictwa interesów seniorów ${ }^{2}$.

Konkurs skierowany jest do osób 60+ i do par międzypokoleniowych, które mają pomysł na projekt społeczny, chcą pracować nad jego rozwojem przy wsparciu ekspertów, doświadczonych animatorów i uczestników programu. Umożliwienie osobom starszym inicjowania działań, w których sami chcą uczestniczyć, które w ich ocenie są potrzebne, pozwala spojrzeć na osoby starsze jako na kreatywnych menedżerów nowych inicjatyw, a nie jedynie odbiorców oferty zaadresowanej do seniorów. Praca ze starszymi liderami, inwestowanie w ich umiejętności wzmacnia obecność osób starszych w społecznościach lokalnych. Natomiast możliwość opracowania i zarządzania projektem przez osoby w różnym wieku sprzyja wymianie doświadczeń, sprawia, że indywidualne umiejętności i predyspozycje twórczo się uzupełniają. Poprzez bliską współpracę senior i osoba młoda pogłębiają swoją świadomość dynamiki i specyfiki relacji międzypokoleniowych (Tokarz-Kamińska, Krzyżanowska 2012).

Udział w konkursie daje możliwość otrzymania wsparcia finansowego w wysokości do 15 tys. zł. O dotacje mogą się ubiegać osoby 60+ lub pary międzypokoleniowe (osoba 60+ i osoba pełnoletnia młodsza o co najmniej 25 lat) we współpracy z organizacją pozarządową czy instytucją, która odgrywa rolę podmiotu aplikującego o dotację (np. Uniwersytet Trzeciego Wieku, fundacja lub stowarzyszenie, dom kultury). Rokrocznie w ramach konkursu dofinansowanych zostaje około 18-22 projektów, które angażują osoby starsze do działania na rzecz otoczenia, włączają osoby starsze w dialog i współpracę z samorządem lokalnym, promują współpracę międzypokoleniową i wolontariat osób starszych. Dotacje są przyznawane na działania mieszczące się w obszarach: edukacja, kultura, działania obywatelskie. Promuje się przedsięwzięcia służące osiąganiu trwałych zmian społecznych na poziomie lokalnym, które wnoszą nową jakość do działań angażujących osoby starsze w danej społeczności i mają potencjał do wypracowania skalowalnych rozwiązań i modeli działania w pracy z osobami starszymi. W latach 2008-2019 dofinansowano łącznie 335 projektów międzypokoleniowych, z czego blisko 30\% stanowiły przedsięwzięcia realizowane w środowiskach wiejskich.

\footnotetext{
i za granicą; udzielanie wsparcia, $w$ tym finansowego, inicjatywom oraz organizacjom i innym podmiotom prowadzącym działalność zbieżną z celami statutowymi; przyznawanie stypendiów indywidualnych; prowadzenie kampanii społecznych oraz stron i portali internetowych; prowadzenie innowacyjnego centrum kultury.

2 http://seniorzywakcji.pl/ (dostęp: 1.10.2019).
} 
Tabela 4. Liczba projektów międzypokoleniowych realizowanych w ramach programu „Seniorzy w akcji” w latach 2008-2019

Table 4. Number of intergenerational projects implemented under the "Seniors in Action" programme in 2008-2019

\begin{tabular}{|c|c|c|c|c|c|c|c|c|c|c|c|c|}
\hline Lata & \&્స & ஜ & 임 & 굠 & 곰 & $\stackrel{m}{\stackrel{n}{N}}$ & : & $\stackrel{n}{\text { กิ }}$ & $\begin{array}{l}0 \\
0 \\
0\end{array}$ & 周 & $\stackrel{\infty}{\stackrel{\infty}{N}}$ & 공 \\
\hline $\begin{array}{l}\text { Liczba } \\
\text { dofinansowanych } \\
\text { projektów }\end{array}$ & 26 & 30 & 26 & 32 & 26 & 30 & 33 & 27 & 28 & 33 & 23 & 21 \\
\hline
\end{tabular}

Źródło: opracowanie własne na podstawie: http://seniorzywakcji.pl/ (dostęp: 1.10.2019).

Source: own study based on: http://seniorzywakcji.pl/ (dostęp: 1.10.2019).

Konkurs „Seniorzy w akcji” realizowany w formule inkubatora stwarza przestrzeń do rozwijania zgłoszonych pomysłów poprzez cykl warsztatów, wizyty studyjne oraz wsparcie trenerów z Sieci Latających Animatorów Kultury i Socjologów (warsztaty, konsultacje). Jego formuła jest przyjazna zwłaszcza dla osób i organizacji, które nie mają dużego doświadczenia w realizacji projektów. Daje możliwość wymiany doświadczeń między uczestnikami programu i w dużej mierze decyduje o skuteczności programu (Tokarz-Kamińska, Krzyżanowska 2012). Dzięki otwartej formule umożliwia realizowanie zróżnicowanych projektów, które wpisują się w cele przedsięwzięcia (wolontariat seniorów, współpraca międzypokoleniowa i zaangażowanie seniorów na rzecz społeczności). Ich różnorodność wynika także z formuły konkursu, który wspiera projekty łączące osobiste pasje i zainteresowania liderów. Najważniejszym kryterium różnicującym działania podejmowane w ramach Programu jest tematyka projektów. Dominują wśród nich:

- artystyczne projekty teatralne (teatr międzypokoleniowy, teatr tańca), fotograficzne, filmowe czy taneczno-muzyczne (chór, taniec, warsztaty jazzowe), a także projekty korzystające $\mathrm{z}$ różnych metod rękodzieła (dzierganie, warsztaty biżuterii, szycia czy filcowania);

- regionalno-historyczne (polegają na zbieraniu informacji o historii miejscowości i jej mieszkańcach, a także o tradycjach i zwyczajach regionalnych - spisywanie wspomnień, starych zabaw czy pieśni, opracowywanie przewodników);

- edukacyjne (e-learning, zajęcia wspierające dziadków w wychowywaniu wnuków).

Ważnym obszarem programu „Seniorzy w akcji” jest międzypokoleniowość, realizowana zarówno na poziomie zarządzania projektem (międzypokoleniowe pary animatorów), jak i na poziomie działań skierowanych do społeczności lokalnej (w których uczestniczą różne grupy wiekowe). 
W projektach realizowanych w ramach programu „Seniorzy w akcji” przeważa międzypokoleniowość jednokierunkowa i dwukierunkowa, oparta na wspólnych działaniach lub wspólnych hobby, oraz tradycyjna, odwołująca się do typowych ról osób starszych, jak również tzw. międzypokoleniowość w uczeniu, nastawiona na zdobywanie nowych kompetencji, przekazywanie wiedzy i uczenie się od siebie nawzajem. Międzypokoleniowość jednokierunkową można sprowadzić do działań, w których starsi mówią i opowiadają, a młodzi słuchają, opisują i raportują. W tym typie międzypokoleniowości na ogół brakuje przestrzeni na skonfrontowanie punktu widzenia młodych z przekonaniami i opiniami starszych uczestników. Z międzypokoleniowością dwukierunkową mamy zaś do czynienia wtedy, gdy młodzi i starsi robią coś razem, wspólnie spędzają czas. Projekty nastawione na wspólne działanie w sposób naturalny integrują ze sobą ludzi w różnym wieku. Międzypokoleniowość tradycyjna daje korzyści obydwu stronom uczestniczącym w projekcie, pozwala seniorom - babciom i dziadkom - realizować się, czuć się potrzebnymi, a dzieciom daje wsparcie i zainteresowanie. Projekty oparte na międzypokoleniowości w uczeniu, czyli działania nastawione na rozwój kompetencji do nawiązywania i utrzymywania kontaktów międzypokoleniowych przez seniorów - wydają się efektywnymi pomysłami, które z powodzeniem budują relacje międzygeneracyjne. Ponieważ projekty prowadzone w ramach Programu mogą być wykonywane przez parę liderów (juniora i seniora) międzypokoleniowość pojawia się nie tylko między uczestnikami projektów, lecz także między animatorami.

Uczestnicy chętnie podkreślają efekty wynikające z udziału w przedsięwzięciu. Wszyscy zgodnie twierdzą, że uczestnictwo we wspólnym projekcie pozwoliło na międzypokoleniową wymianę doświadczeń, nauczyło ich zasad pozytywnej komunikacji i było świetną okazją do wspólnego spędzania czasu. Seniorzy zyskali pewność siebie i odwagę do podejmowania kolejnych działań. Nauczyli się, jak kreować ciekawe pomysły. Poczuli się dowartościowani i doceniani przez osoby młode. Mieli satysfakcję z możliwości przebywania razem i podejmowania wspólnych decyzji. Utwierdzili się w przekonaniu, że każdy wiek jest dobry, aby być aktywnym - fizycznie i intelektualnie. Uczestnictwo w projekcie wzmocniło także poczucie wartości wśród młodych osób, nauczyło ich tolerancji i empatii, jak również otworzyło na starszych. Juniorzy przekonali się, że osoby starsze są przyjazne, energiczne, pomysłowe i kreatywne.

Poza zaplanowanymi efektami budowania pozytywnej więzi międzypokoleniowej, wpisanymi we wspólną aktywność poznawczą oraz twórczą, realizacja omawianego projektu dawała okazję do rozwijania kompetencji w obszarze takich zadań, które same w sobie naturalnie tworzyły i umacniały więzi międzypokoleniowe. 
Podjęte w ramach konkursu inicjatywy pozwoliły nie tylko wykorzystać energię seniorów, ale także obalić stereotypy dotyczące obu generacji.

Warto dodać, że konkurs „Seniorzy w akcji” znalazł się w gronie dwudziestu finalistów europejskiego konkursu „Społeczne Innowacje w Starzeniu” (Social Innovations in Ageing) ${ }^{3}$, gdzie doceniono model wspierania osób 60+ w roli liderów działań społecznych, a także schemat tworzenia przestrzeni do współpracy i dialogu pokoleń, wypracowany w realizowanym programie. Celem konkursu były promocja i wspieranie innowacji społecznych w obszarze aktywnego i zdrowego starzenia się w Europie.

\section{Podsumowanie}

Potrzeba dialogu międzypokoleniowego wynika m.in. ze skomplikowanych przemian XX wieku, zwłaszcza zaś z przepaści komunikacyjnej między pokoleniami. Zakłóca ten dialog nadmierna ilość napływających informacji. Zdaniem Ewy Wiśniewskiej (2017), dialog międzypokoleniowy to sprawa nas wszystkich i każdego z osobna, gdyż właściwe interpretowanie świata i rozumienie siebie nie jest możliwe bez spotkań międzypokoleniowych. Relacje międzypokoleniowe nie są w związku z tym tylko formą kontraktu, lecz także podlegają rozlicznym normom. Konieczne wydaje się więc moderowanie relacji międzypokoleniowych, tak aby stworzyć prawdziwie dialogowy kontekst wspólnego działania, oparty na zrozumieniu potrzeb osób przynależących do różnych pokoleń. Należy zatem zmierzać do tego, by dialog międzypokoleniowy stał się rzeczywistym działaniem, a nie jedynie postulatem w literaturze przedmiotu. Istotne jest, by stwarzać okazje do spotkań, by dzielić się między sobą własnym sposobem postrzegania świata, preferowanymi wartościami, kulturą, tradycją (Zych 2007). Zdaniem Leona Dyczewskiego (1994), społeczeństwo - nawet najbardziej nastawione na nowoczesność - nie może się obyć bez ludzi starszych.

W obliczu trudności ekonomicznych rośnie społeczne ryzyko odsunięcia niektórych potrzeb starszych pokoleń. By temu zapobiec, warto pielęgnować i promować ideę solidarności $z$ seniorami, a także uświadamiać $i$ uwrażliwiać młodsze pokolenia na sytuację osób starszych, ich możliwości, oczekiwania i potrzeby. Problem integracji międzypokoleniowej jest niezmiernie ważny we współczesnej rzeczywistości. Poprzez nawiązywanie osobistych relacji z seniorami ludzie młodzi mogą poznać specyfikę "jesieni życia” i funkcjonowania osób w podeszłym wieku, a przez to przygotować się do odgrywania przyszłych ról społecznych.

3 Organizatorem konkursu była The King Baudouin Foundation z siedzibą w Brukseli wspólnie z La Caixa Foundation \& Unicredit Foundation. 
Dialog międzypokoleniowy stanowi więc istotny element przygotowania do starości jednostek i społeczeństwa. Porozumienie między generacjami nie jest zadaniem łatwym. Sam proces komunikacji międzyludzkiej jest złożony i wymaga od obu stron zaangażowania i akceptacji. Należy stwarzać okazje do wzajemnego poznawania się osób starszych i młodszych, budowania płaszczyzny porozumienia, a w konsekwencji solidarności międzypokoleniowej. Współcześnie porozumienie między pokoleniami jest tym trudniejsze, że współczesne pokolenie wychowało się w erze zaawansowanej technologii oraz nadmiaru informacji rynkowej. Z kolei przedstawiciele starszego pokolenia mogą zostać $\mathrm{z}$ tego powodu zbyt łatwo wykluczeni w wielu wymiarach społecznych, ekonomicznych czy politycznych.

Kiedyś pokolenia zmieniały się co 25-30 lat i następowały kolejno jedno po drugim, a teraz już co dekada, to inna generacja. Obecnie obok siebie żyją ludzie z pokoleń $\mathrm{BB}, \mathrm{X}, \mathrm{Y}, \mathrm{Z}^{4}$, a zatem umiejętności komunikacji, wzajemnego zrozumienia i słuchania nabierają coraz większego znaczenia (Karmolińska-Jagodzik 2012; Wiśniewska 2017). Kluczem do pogłębionego dialogu międzypokoleniowego powinna być świadomość niebezpieczeństw kryjących się za egocentryzmem pokoleniowym - za wywyższaniem własnego poglądu na świat przy jednoczesnym odmawianiu spoglądania nań z perspektywy innych pokoleń. Dlatego w celu przeciwdziałania osamotnieniu i wykluczeniu społecznemu osób należących do różnych generacji należy tworzyć przyjazną przestrzeń ułatwiającą spotkania międzypokoleniowe i dialog. Relacje międzypokoleniowe cechuje pewna różnorodność, która $\mathrm{w}$ dużej mierze wypływa z różnicy wieku. Programy i projekty międzypokoleniowe powinny odnosić się do budowania relacji osób młodszych zarówno z osobami $60+$, jak i 80+, z uwzględnieniem różnorodności ich indywidualnych potrzeb i możliwości, zwłaszcza seniorów.

Mając na względzie innowacyjne myślenie o parytecie międzypokoleniowym, dochodzimy do konkluzji, że konieczne jest stworzenie nowej jakości współodpowiedzialności publicznej na poziomie mikro- i makrospołecznym jako zrównoważonej koncepcji, uwzględniającej zaspokajanie potrzeb obecnych pokoleń bez umniejszania szans kolejnych generacji na ich zaspokojenie (Święcicka 2015).

4 Potocznie określane pokolenie baby boomers (BB) reprezentują osoby urodzone w latach 1946-1964, tj. powojenne pokolenie wyżu demograficznego. Pokoleniem X nazywa się zaś osoby, które urodziły się na przełomie lat 1965-1979. Pokolenie Y, określane mianem „milenialsów”, reprezentują urodzeni w latach 1980-1994. Przedstawiciele pokolenia C (inaczej nazywanego pokoleniem Z lub XD) to osoby urodzone po roku 1994 (które zasadniczo nie wyobrażają sobie życia bez internetu). 


\section{Bibliografia}

Bengtson V.L., Giarrusso R., Mabry J.B., Silverstein M. (2002). Solidarity, conflict, and ambivalence: Complementary or competing perspectives on intergenerational relationships. Journal of Marriage and Family, 64, 568-576.

Biggs S., Lowenstein A. (2011). Generational Intelligence. A critical Approach to Age Relations. London: Routledge.

Bukraba-Rylska I. (2008). Socjologia wsi polskiej. Warszawa: Wydawnictwo Naukowe PWN. Chałasiński J. (oprac.) (1964). Młode pokolenie wsi Polski Ludowej. Pamiętniki i studia. Tom 1: Awans pokolenia. Warszawa: Ludowa Spółdzielnia Wydawnicza.

Chałasiński J. (1984) (reprinty wydania z 1938 r.). Młode pokolenie chłopów. Tomy IIV. Warszawa: Ludowa Spółdzielnia Wydawnicza.

Czerwiński M. (1969). Przemiany obyczaju. Warszawa: Państwowy Instytut Wydawniczy.

Drozd-Piasecka M. (1991). Ziemia w społeczności wiejskiej. Studium wsi południowo-wschodniego Mazowsza (koniec XIX i XX wiek). Warszawa: Wydawnictwo Instytutu Historii Kultury Materialnej PAN.

Dyczewski L. (1994). Ludzie starzy i starość w społeczeństwie i kulturze. Lublin: Katolicki Uniwersytet Lubelski.

Fedyszak-Radziejowska B. (2002). Liderzy i ich organizacje w rozwoju społeczno-gospodarczym wsi. W: M. Kłodziński, B. Fedyszak-Radziejowska (red.). Przedsiębiorczość wiejska $w$ Polsce i krajach Unii Europejskiej (s. 245-265). Warszawa: IRWiR PAN.

Godlewski G. (2002). Animacja i antropologia. W: G. Godlewski, I. Kurz, A. Mencwel, M. Wójtowski (red.). Animacja kultury. Doświadczenie i przyszłość (s. 56-67). Warszawa: Instytut Kultury Polskiej UW.

Griese H.M. (1996). Socjologiczne teorie młodzieży. Kraków: Impuls.

Halamska M. (1991). Chłopi polscy na przełomie epok. Warszawa: IRWiR PAN.

Hoff W. (2013). Budowanie dialogu międzypokoleniowego. Wnioski z doświadczeń zagranicznych. W: M. Rosochacka-Gmitrzak, A. Chabiera (red.). Dialog międzypokoleniowy. Między idea a praktyka. Inspiracje (s. 47-55). Biuletyn „Zasada równego traktowania. Prawo i praktyka", 10. Warszawa: Biuro Rzecznika Praw Obywatelskich.

Kalinowska M. (2011). Młodość vs starość - o potrzebie dialogu międzypokoleniowego. W: N. Majchrzak, A. Zduniak (red.). Komunikowanie się w społeczeństwie wiedzy XXI wieku (s. 157-168). Poznań: Wydawnictwo Wyższej Szkoły Bezpieczeństwa.

Karmolińska-Jagodzik E. (2012). Komunikacja międzypokoleniowa - rozważania wokół różnic kulturowych. Studia Edukacyjne, 21, 191-210.

Klimczuk A. (2010). Bariery i perspektywy integracji międzypokoleniowej we współczesnej Polsce. W: D. Kałuża, P. Szukalski (red.). Jakość życia seniorów w XXI wieku z perspektywy polityki społecznej (s. 92-107). Łódź: Wydawnictwo Biblioteka.

Komendera A. (1985). Tradycyjna wiejska zbiorowość jako system społeczny. Prace Filozoficzne, 95 (4), 207-232.

Koyano W. (2003). Intergenerational relationships of Japanese seniors: Changing patterns. W: V.L. Bengtson, A. Lowenstein (eds.). Global ageing and challenges to families (s. 272283). New York: Aldine de Gruyter. 
Magiera E. (2010). Relacje między pokoleniami na przestrzeni wieków. W: B. Bugajska (red.). Młodość i starość. Integracja pokoleń. Szczecin: Zapol.

Mannheim K. (1966). Das Problem der Generationen. W: L. von Friedeburg (Hrsg.). Jugend in der modernen Gesellschaft. Berlin-Köln.

Markowska D. (1976). Rodzina w społeczności wiejskiej - ciagłość i zmiana. Warszawa: Ludowa Spółdzielnia Wydawnicza.

Matysiak I. (2019). Młodzi i wykształceni w procesie przemian polskiej wsi. Warszawa: Wydawnictwo Naukowe Scholar.

Mead M. (1978). Culture and Commitment: The New Relationships between the Generations in the 1970s. New York: Columbia University Press.

Mencwel A. (2017). Toast na progu. Kraków: Wydawnictwo Literackie.

Niezabitowski M. (2007). Ludzie starsi w perspektywie socjologicznej. Problemy uczestnictwa społecznego. Katowice: Biblioteka Pracownika Socjalnego.

Nowak P. (2012). Praca na roli i produkcja rolna. Autoportret, 4 (39), 52-56.

Osoby starsze w oczach młodzieży, młodzież w oczach starszych. Raport z badania jakościowego przeprowadzonego na zlecenie Biura RPO (2012). Warszawa: Dom Badawczy Maison.

Ossowska M. (1963). Koncepcja pokolenia. Studia Socjologiczne, 2, 47-51.

Phillips J., Ajrouch K., Hillcoat-Nallétamby S. (2010). Key concepts in social gerontology. London: Sage.

Raszeja-Ossowska I. (2016). Działać międzypokoleniowo. Poradnik witryny wiejskiej. http:// witrynawiejska.org.pl/data/generacje_24_3_2016.pdf (dostęp: 30.09.2019).

Rosochacka-Gmitrzak M., Chabiera A. (2013). Słowo wstępne. Od konfliktu i ambiwalencji do dialogu - ku zrównoważonym i inteligentnym relacjom międzypokoleniowym. W: M. Rosochacka-Gmitrzak, A. Chabiera (red.). Dialog międzypokoleniowy. Między ideą a praktyką. Inspiracje (s. 5-10). Biuletyn „Zasada równego traktowania. Prawo i praktyka”, 10. Warszawa: Biuro Rzecznika Praw Obywatelskich.

Spiker P. (2008). Social Policy Themes and Approaches. Bristol: Policy Press.

Sulima M. (2008). Rola religii w kształtowaniu przestrzeni domu wiejskiego. Zeszyty Naukowe Politechniki Białostockiej, Architektura, 21, 81-91.

Szarota Z. (2014). Edukacja trzeciego wieku - implikacje edukacyjne. Edukacja ustawiczna dorostych, 1 (84), 7-18.

Szczepański J. (1988). Chłopi i kultura chłopska w społeczeństwie polskim. Warszawa: Ludowa Spółdzielnia Wydawnicza.

Szukalski P. (2002). Przepływy międzypokoleniowe i ich kontekst demograficzny. Łódź: Wydawnictwo Uniwersytetu Łódzkiego.

Szukalski P. (2012). Solidarność pokoleń. Dylematy relacji międzypokoleniowych. Łódź: Wydawnictwo Uniwersytetu Łódzkiego.

Szatur-Jaworska B., Błędowski P., Dzięgielewska M. (2006). Podstawy gerontologii społecznej. Warszawa: Oficyna Wydawnicza Aspra.

Sytuacja demograficzna osób starszych i konsekwencje starzenia się ludności Polski w świetle prognozy na lata 2014-2050 (2014). Warszawa: GUS. 
Święcicka A. (2015). Solidarność międzypokoleniowa: anachronizm czy szansa na nowoczesny wymiar zrównoważonej współodpowiedzialności społecznej? Świat Idei i Polityki, 14, 431-447.

Tokarz-Kamińska B. (2013). Jak kształtować partnerskie relacje między pokoleniami? W: M. Rosochacka-Gmitrzak, A. Chabiera (red.). Dialog międzypokoleniowy. Między ideq a praktyka. Inspiracje (s. 43-46). Biuletyn „Zasada równego traktowania. Prawo i praktyka”, 10. Warszawa: Biuro Rzecznika Praw Obywatelskich.

Tokarz-Kamińska B., Krzyżanowska Ł. (2012). Dobre praktyki w działaniach międzypokoleniowych na podstawie doświadczeń programu „Seniorzy w akcji”. Problemy Polityki Społecznej, 17, 167-181.

Wieruszewska M. (1991). Wieś. W poszukiwaniu całości społeczno-kulturowej. Warszawa: PWN.

Wiśniewska E. (2017). Starsi i młodzi w dialogu międzypokoleniowym. Społeczeństwo -Edukacja - Język, 6, 27-47.

Wnuk W. (2013). O potrzebie kształtowania relacji międzypokoleniowych. W: M. Rosochacka-Gmitrzak, A. Chabiera (red.). Dialog międzypokoleniowy. Między idea a praktyką. Inspiracje (s. 56-67). Biuletyn „Zasada równego traktowania. Prawo i praktyka”, 10. Warszawa: Biuro Rzecznika Praw Obywatelskich.

Woźniak Z. (2012). Solidarność międzypokoleniowa w starzejącym się świecie - perspektywy i zagrożenia. Ruch Prawniczy, Ekonomiczny i Socjologiczny, 3, 21-63.

Zawistowicz-Adamska K. (1958). Społeczność wiejska. Wspomnienia i materiały z badań terenowych Zaborów 1937-1938. Warszawa: Ludowa Spółdzielnia Wydawnicza.

Zych A. (2007). Leksykon gerontologii. Kraków: Wydawnictwo Impuls. 


\title{
Intergenerational Dialogue and Social Activation of Older People in the Rural Environment
}

\begin{abstract}
Intergenerational relations form the basis of how every society functions. One of the ways to develop these relations is through intergenerational dialogue, which can also prevent and counteract modern social problems. However, this requires the active participation of both the young and the elderly. The article is an attempt to capture the essence of intergenerational dialogue and emphasise its role in the rural environment. To this end, the study combines theoretical considerations with a description of practical solutions (example of the "Seniors in Action" programme). A significant issue of the "Seniors in Action" programme is the idea of intergenerationality implemented at the projectmanagement level (pairs of cultural operators representing different generations) as well as at the level of activities addressed to a local society including people of different ages. In a rural environment it is also possible to build intergenerational bonds based on neighbourly relations, where contacts between many generations are part of everyday life, as well as in interest groups (e.g. NGOs, rural community centres) whose purpose is to solve the problems of local communities. Effective dialogue is an exchange of values that brings profits to the entire local community.
\end{abstract}

Keywords: dialogue, generation, intergenerational relations, intergenerational dialogue. 